УДК 622.882+631.425+631.427, DOI 10.31210/visnyk2018.04.17

(C) 2018

Маслікова К. П., кандидат біологічних наук

Дніпровський державний аграрно-економічний університет

Жуков О. В., доктор біологічних наук

Дніпровський національний університет імені Олеся Гончара

Коваленко Д. В., здобувач

Мелітопольський державний педагогічний університет імені Богдана Хмельницького

\title{
ФІТОІНДИКАЦЙНА ОЦІНКА РЕЖИМУ ОСВІТЛЕННЯ ЯК МАРКЕР РЕГУЛЯТОРНИХ ЕКОСИСТЕМНИХ СЕРВІСІВ У ТЕХНОЗЕМАХ НІКОПОЛЬСЬКОГО МАРГАНЦЕВОРУДНОГО БАСЕЙНУ
}

\section{Рецензент - доктор сільськогосподарських наук П. В. Писаренко}

\begin{abstract}
Показана можливість індикації регуляторних екосистемних сервісів протягом техногенного грунтогенезу за допомогою фітоіндикаційних оцінок режиму освітлення. У якості маркерів регуляторних екосистемних сервісів у процесі техногенного грунтогенезу можуть бути застосовані фітоіндикаційні оцінки режиму освітлення. Причинами трансформації світлової структури рослинного угруповання техноземів $\epsilon$ варіювання густини рослинного покриву та його архітектоніки. Зміни світлової структури є найважливішими маркерами пертинетного впливу рослинного покриву на мікрокліматичні умови. Динаміка змін режиму освітлення протягом грунтогенезу має тенденцію до формування більи затінених рослинних угруповань.
\end{abstract}

Ключові слова: екосистемні сервіси, рекультивачія, фітоіндикачія, режим освітлення, сталий розвиток.

Постановка проблеми. Агропромисловий комплекс $є$ найважливішим фактором розвитку вітчизняної економіки. Сталий розвиток агросфери є умовою добробуту та розвитку нації. Основою виробництва продовольства є сільське господарство. Землі сільськогосподарського користування займають близько $40 \%$ поверхні суші [23], і агроценози можна розглядати як найбільший сучасний біом суші [12]. Досягнення екологічно обгрунтованого рівня агропромислового виробництва потребує розробки та впровадження інноваційних технологій менеджменту агроекосистем [28-30].

Гармонізація стратегій досягнення цих цілей потребує розробки технологій менеджменту та алгоритмів їх впровадження на різних ієрархічних рівнях агроекосистем. Важливим завданням $\epsilon$ конвертація цілей підсистем у термінах комплементарних складових: як екологічні цілі виглядають 3 боку агротехнологічної та економіко- соціальної складових, та відповідно агротехнологічні та економіко-соціальні цілі з боку інших [30]. Тому розробка методологічних підходів для пошуку кількісних показників комплексної оцінки стану агроекосистем $є$ важливою науковою проблемою.

Аналіз останніх досліджень і публікацій, у яких започатковано розв'язання проблеми. Екосистемні сервіси - це умови та процеси, завдяки яким природні екосистеми та види, які їх складають, підтримують та забезпечують життя людини [5]. Виділені наступні типи екосистемних сервісів: підтримуючі - необхідні для виконання усіх інших екосистемних сервісів (грунтоутворення, кругообіг поживних речовин, первинна продуктивність); забезпечуючі - продукти, які можуть бути одержані від екосистем (продукти, вода, а також генетичні ресурси); регуляторні - регуляція клімату, розкладання забруднюючих речовин, контроль шкідників та хвороб, опилення; культурні - нематеріальні вигоди, які одержують люди від природи (рекреація та екотуризм, освіта та ін.) [25].

Відповідно до Стратегії Біорізноманіття Свросоюзу (Ціль 2, Дія 5) стан екосистем та екосистемні сервіси у країнах-членах Європейського союзу повинні бути визначені та позначені картографічно [26]. Економічне значення екосистемних сервісів також повинно бути встановлене та інтеграція таких оцінок повинна враховуватися як на рівні EC, так і на національних рівнях [2].

Економічна оцінка екосистемних сервісів найважливіша практична та теоретична проблема у сучасній науці $[13,18,19]$. Найбільш важливими екосистемними сервісами у сільському господарстві є: опилення, природний контроль шкідників сільського господарства, підтримання 


\section{СІЛЬСЬКЕ ГОСПОДАРСТВО. ЕКОЛОГІЯ}

родючості грунтів, охорона біологічного різноманіття та біотопів, які $\epsilon$ вмістилищем цього різноманіття $[1,4,10,15-17]$.

Біологічне різноманіття та пов'язані екосистемні процеси забезпечують екосистемні сервіси iз залученням великої кількості видів для виконання більш ніж одного екосистемного сервісу.

Не дивлячись на фундаментальну важливість грунту у сільському господарстві економічні оцінки негативного впливу на грунт обмежуються переважно ерозією та забрудненням, при цьому значення біологічного різноманіття грунтової біоти майже не досліджено [24].

Видобуток корисних копалин відкритим способом призводить до повного руйнування грунтового покриву - основи біогеоценозу, а також знищує фіто-, зоо- та мікробоценотичний блоки біогеоценозу. Для розробки найефективніших та раціональних методів рекультивації велике значення має дослідження процесів їх природної еволюції - відновлення рослинного покриву та тваринного населення як інформативних компонентів біогеоценозу [14, 28].

Ми пропонуємо розглядати рекультивацію як систему заходів із відновлення екосистемних сервісів біоти. У цьому зв'язку актуальною проблемою $є$ можливість кількісної оцінки екосистемних сервісів.

Трофічні мережі грунтових редуцентів відіграють найважливішу роль у ключових екосистемних сервісах, таких як грунтоутворення, кругообіг поживних речовин та зберігання вуглецю у грунті [7].

У природних екосистемах переважна більшість первинної продукції потрапляє у грунт, де вона розкладається та поступово перетворюється у поживні речовини та оксид вуглецю, який повертається в атмосферу. В той же час трофічні мережі грунтових редуцентів роблять внесок в стабілізацію грунтової органічної речовини, яка формує важливий пул вуглецю [22].

Екстенсивне використання добрив та оранка, які застосовуються в сучасних моделях землеробства, заміщують багато дій, які виконуються мережами грунтових редуцентів у природних екосистемах, що у свою чергу знижує різноманіття та активність грунтової біоти [7].

Зміна типів землекористування, порушення оселищ, інвазивні види, ущільнення грунту, ерозія, забруднення та зменшення вмісту органічної речовини у грунті, надлишковий прес на біологічне різноманіття - такі негативні тренди спостерігаються на площі понад 25 \% території Свропейського союзу, а $8 \%$ території зазнає дуже великого впливу [11].

Інтенсивне землеробство призводить до зменшення біологічного різноманіття грунтів та робить угруповання грунтової біоти менш різноманітним та таким, що представлене більш малими за розмірами групами організмів. Великі за розмірами грунтові організми більш чутливі до інтенсифікації сільськогосподарського виробництва [27].

Нашою робочою гіпотезою $є$ те, що фітоіндикаційні оцінки екологічних режимів, які можуть бути одержані на основі дослідження рослинних угруповань, що формуються на техноземах, можуть бути маркерами активності екосистемних сервісів.

Показано, що опорні екосистемні сервіси можна діагностувати за допомогою фітоіндикаційних шкал мінералізованності, трофності та кислотності едафотопу [20].

Мета нашої роботи - показати можливість індикації регуляторних екосистемних сервісів протягом техногенного грунтогенезу за допомогою фітоіндикаційних оцінок режиму освітлення.

Матеріали та методи. Польові дослідження проводилися протягом 2008-2017 рр. у дослідній біоекологічній станції Дніпровського аграрноекономічного університету (м. Покров, Дніпропетровська область, Україна) [28]. Полігони закладені у межах чотирьох типів техноземів: педоземи, дерново-літогенні грунти на лесоподібних суглинках, сіро-зелених глинах та червонобурих глинах. Полігон складається з 15 трансект, а кожна трансекта складена 37 пробних майданчиків. Відстань між рядами в полігоні становить 3 м. Кожний майданчик представляє собою квадрат розміром $3 \times 3$ м. У межах кожного майданчика було проведено геоботанічний опис рослинності.

Відомості про динаміку заростання відвалів на фазі формування ембріоземів протягом першого періоду сукцесії $(2,4,6,8$ років) взяті з роботи М. Т. Масюка [21].

Відомості про стан рослинного угруповання на техноземах віком 39, 40, 41 та 42 роки - власні експериментальні результати [20].

Часова динаміка змін фітоіндикаційних показників була апроксимована рівнянням Хілла, яке має вигляд:

$$
Y=\frac{T^{n}}{T^{n}+E^{n}}
$$

де $\mathrm{Y}$ - екологічний фактор; Т - час існування технозему, роки; n та К - константи. Коефіцієнт Хілла знайдений як вільний член лінійної залежності, побудованої у координатах $\log \mathrm{T}$ - ось абс- 


\section{СІЛЬСЬКЕ ГОСПОДАРСТВО. ЕКОЛОГІЯ}

цис, $\log (\mathrm{Y} /(\mathrm{Ymax}-\mathrm{Y}))$ - ось ординат.

Коефіцієнт Хілла характеризує кооперативність динаміки процесу. В разі коефіцієнта Хілла, який більше 1 , спостерігається позитивний кооперативний ефект, за коефіцієнта Хілла, який менший $1,-$ негативний кооперативний ефект, якщо коефіцієнт дорівнює одиниці - кооперативний ефект відсутній.

Я. П. Дідух [8] виділяє едафічні та кліматичні фітоіндикаційні шкали.

До едафічних належать показник гідроморф $(\mathrm{Hd})$, змінність зволоження (fH), аерація (Ae), кислотний режим ( $\mathrm{Rc})$, сольовий режим ( $\mathrm{Sl})$, вміст карбонатних солей $(\mathrm{Ca})$, вміст у грунті засвоюваних форм азоту (Nt).

До кліматичних належать шкали за чотирма факторами: терморежим (Tm), омброрежим $(\mathrm{Om})$, кріорежим $(\mathrm{Cr})$ і континентальність клімату $(\mathrm{Kn})$.

Крім зазначених, виділяється ще шкала освітлення (Lc), яку можна охарактеризувати як мікрокліматичну шкалу.

Можна припустити, що едафічні шкали та шкала освітлення будуть чутливі до варіабельності властивостей грунту на рівні окремої точки, що може бути основою для застосування фітоіндикаційних шкал для великомасштабного картографування. Теплові властивості грунтів індикуються шкалою терморежиму, а гідротермічні - шкалою омброрежима (Didukh, 2011).

Фітоіндикаційні шкали наведені за
Я.П.Дідухом [8]. Фітоіндикаційна оцінка градацій екологічних факторів проведена за Г. Н. Бузуком [3].

Результати дослідження. Розподіл вегетативної маси окремих компонентів складних багатокомпонентних агрофітоценозів, взаємний вплив надземних органів компонентів одне на одного та екологічні умови під пологом травостою мають суттєвий вплив на формування врожайності фітоценозів. За більш рівномірного розподілу листових пластинок в фітоценозі ослаблення освітлення на рівні середнього та нижніх ярусів не буде дуже великим. Це обумовлює найвищу інтенсивність функціонування фотосинтезу травостою на одиниці площі.

У послідовності «ембріоземи $\rightarrow$ дерноволітогенні грунти $\rightarrow$ педоземи» рівень фітоіндикаційної оцінки освітлення статистично вірогідно знижується $(\mathrm{F}=32,84, \mathrm{p}=0,00)$. Трав'яниста рослинність, яка переважно формує покрив техноземів, формується в умовах світового або субсвітового режиму освітлення. Рослинний покрив ембріоземів вказує на режим освітлення $8,78 \pm 0,01$, дерново-літогенних грунтів $8,74 \pm 0,02$, педоземів - 8,71 $\pm 0,01$.

Серед ембріоземів найбільш освітлені умови формуються на червоно-бурих та сіро-зелених глинах (рис. 1).

Серед дерново-літогенних грунтів найбільш освітлені умови характерні для червоно-бурих глин.

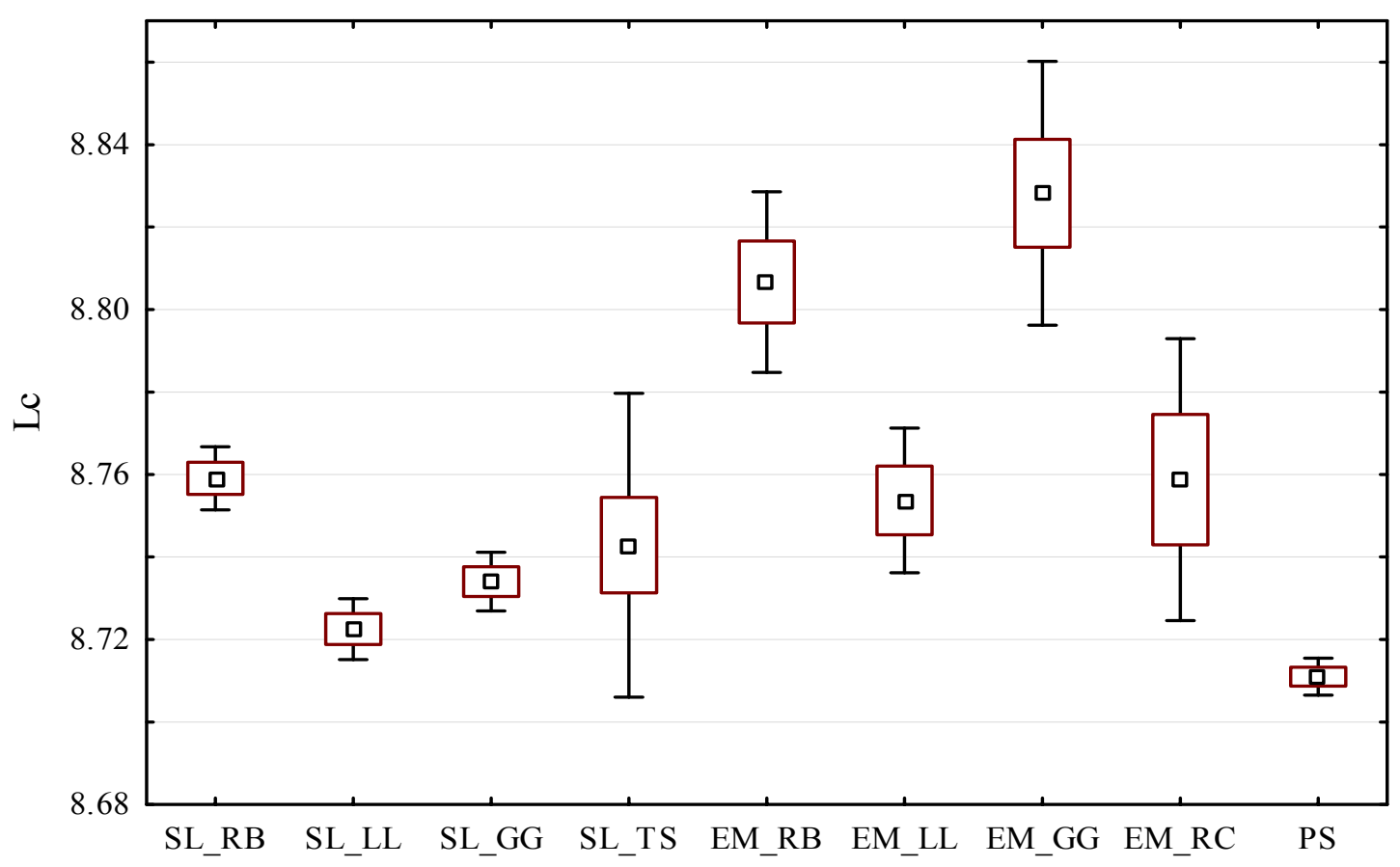

Рис. 1. Фітоіндикаційна оцінка режиму освітлення 


\section{СІЛЬСЬКЕ ГОСПОДАРСТВО. ЕКОЛОГІЯ}

Умовні позначки:

SL_RB - дерново-літогенні грунти на червонобурих глинах;

SL_LL - дерново-літогенні грунти на лесоподібних суглинках;

SL_GG - дерново-літогенні грунти на сірозелених глинах;

SL_TS - дерново-літогенні грунти на технологічній суміші гірських порід;

EM_RB - ембріоземи на червоно-бурих глинах;

EM_LL - емріоземи на лесоподібних суглинках;

EM_GG - ембріоземи на ссіро-зелених глинах;

EM_RC - ембріоземи на червоно-бурих суглинках;

PS - педоземи.

Найбільш тіньова світлова структура формується в рослинному угрупованні на лесоподібних

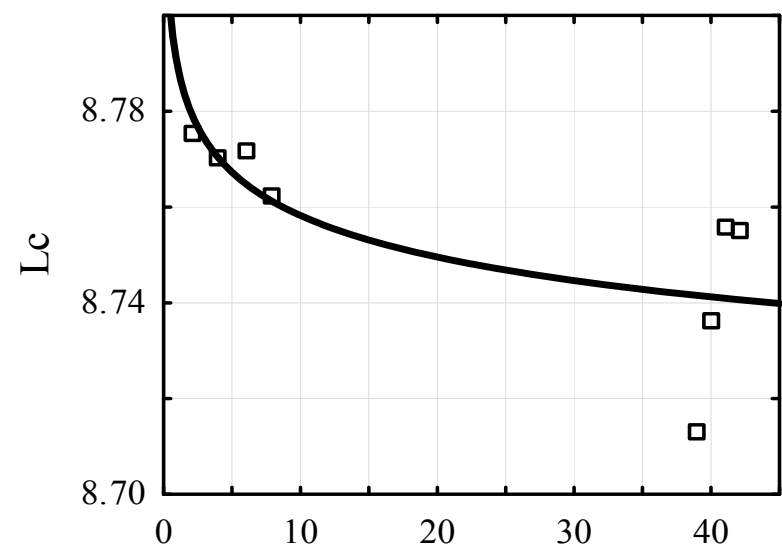

Червоно-бурі глини суглинках, яка дуже наближається до показників світлової структури педоземів.

Очевидно, що причинами трансформації світлової структури рослинного угруповання $є$ варіювання густини рослинного покриву та його архітектоніки.

Зміни світлової структури є найважливішими маркерами пертинетного впливу рослинного покриву на мікрокліматичні умови.

Вірно і зворотне: зростання родючості техноземів протягом грунтогенезу формують умови для формування більш щільного та більш складно організованого рослинного покриву. Динаміка змін режиму освітлення протягом грунтогенезу має тенденцію до формування більш затінених рослинних угруповань (рис. 2).

Стаціонарні рівні режиму освітлення дуже подібні між собою для різних типів техноземів (табл. 1).

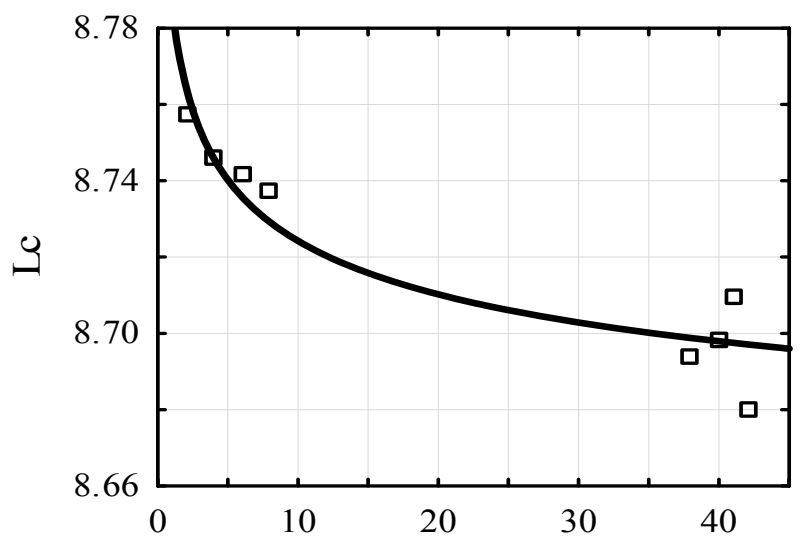

Лесоподібні суглинки

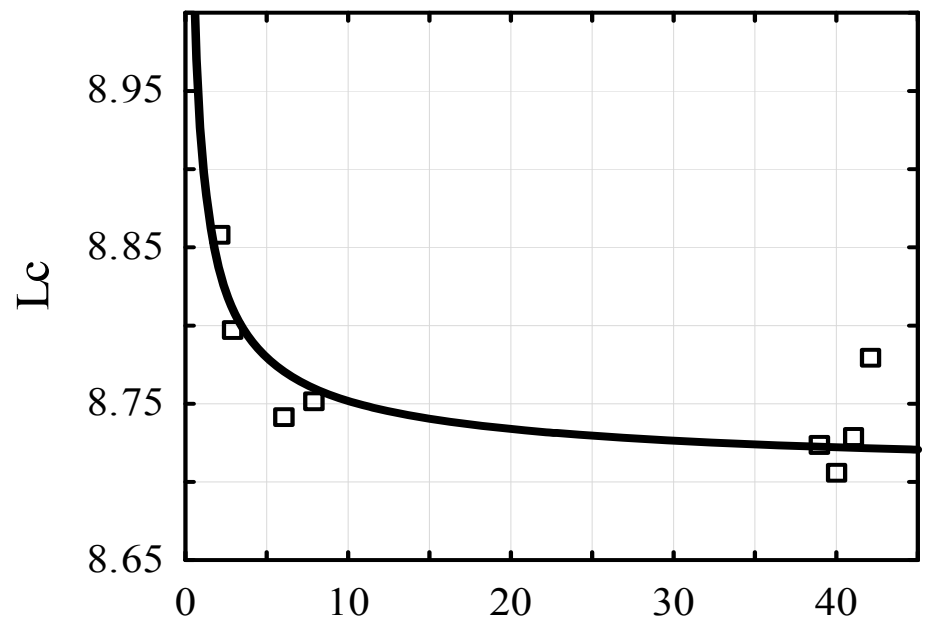

Сіро-зелені глини

Рис. 2. Динаміка фітоіндикаційних оцінок режиму освітлення у процесі трунтогенезу 
СІЛЬСЬКЕ ГОСПОДАРСТВО. ЕКОЛОГІЯ

1. Рівняння динаміки фітоіндикаційних оцінок режиму освітлення $(Y)$ у часі трунтогенезу $(x)$

\begin{tabular}{|l|c|c|c|c|}
\hline \multicolumn{1}{|c|}{ Субстрат } & \multicolumn{1}{c|}{ Рівняння } & $\begin{array}{c}\text { Число } \\
\text { Хілла }\end{array}$ & $T_{50}$ років & Lc \\
\hline Червоно-бурі глини & $Y=8,55+100 * x^{-0.06} /\left(x^{-0.06}+416\right)$ & 1,09 & 24,9 & 8,55 \\
\hline Лесоподібні суглинки & $Y=8,61+100 * x^{-0.19} /\left(x^{-0.19}+566\right)$ & 1,03 & 8,85 & 8,61 \\
\hline Сіро-зелені глини & $Y=8,70+100 * x^{-0.61} /\left(x^{-0.61}+468\right)$ & 1,39 & 8,03 & 8,70 \\
\hline
\end{tabular}

Це свідчить про те, що рослинний покрив здатний адаптуватися до широкого кола екологічних умов та сформувати таке угруповання, структура та функціонування якого будуть адекватні зовнішнім чинникам.

Особливість становить динаміка досягнення стаціонарного стану. Розрахунки вказують на те, що динаміка стабілізації світлової структури рослинності на лесоподібних суглинках та на сірозелених глинах відбувається майже синхронно та дуже швидко.

У той час як стабілізація світлової структури рослинності на червоно-бурих відбувається за значно більш тривалий період. Складність механізмів динаміки, яку відображають числа Хілла, $\epsilon$ одного рівня для рослинних угрупованнях на різних типах техноземів.

Зниження інтенсивності освітлення, яке часто має місце в штучних та природних фітоценозах внаслідок затінення низькорослих рослин високорослими, призводить до падіння інтенсивності фотосинтезу та загальної продуктивності фітоценозу. В разі затінення рослини набувають здатності більш ефективно використовувати слабе

\section{БІБЛІОГРАФІЯ}

1. Albrecht M., Schmid B., Hautier Y., Müller C.B. (2012). Diverse pollinator communities enhance plant reproductive success. Proceedings of the Royal Society of London B 279, 4845-4852. doi: 10.1098/rspb.2012.1621.

2. Brouwer R., Brander L., Kuik O., Papyrakis E. and Bateman I. A synthesis of approaches to assess and value ecosystem services in the EU in the context of TEEB. University Amsterdam Institute for Environmental Studies, 2013.

3. Buzuk G.N. (2017). Phytoindication with ecological scales and regression analysis: environmental index. Bulletin of Pharmacy, 2 (76), 31-37.

4. Chagnon M., Gingras J., DeOliveira D. Complementary aspects of strawberry pollination by honey and indigenous bees (Hymenoptera). Journal of Economic Entomology, 1993 86(2), 416-420. https://doi.org/10.1093/jee/86.2.416.

5. Daily G. C. Nature's Services: Societal світло, зменшують витрати енергії на дихання, в них збільшується висота пагонів та довжина міжвузлів та листових пластинок, але зменшується їх ширина та товщина, зменшується число пагонів та коренів, а також глибина проникнення коренів у грунт (вага кореневих систем у випадку затінення зменшується в більшій мірі ніж вага надземних пагонів). У бобових у разі затінення зменшується утворення бульбочок на коренях та інтенсивність азотфіксації.

Висновки. У якості маркерів регуляторних екосистемних сервісів у процесі техногенного грунтогенезу можуть бути застосовані фітоіндикаційні оцінки режиму освітлення.

Причинами трансформації світлової структури рослинного угруповання техноземів $є$ варіювання густини рослинного покриву та його архітектоніки.

Зміни світлової структури є найважливішими маркерами пертинетного впливу рослинного покриву на мікрокліматичні умови.

Динаміка змін режиму освітлення протягом грунтогенезу має тенденцію до формування більш затінених рослинних угруповань.

Dependence on Natural Ecosystems. Island Press, Washington, 1997. $-392 \mathrm{p}$.

6. Davitaia F.F., Melnik J.S. Forecasting problem of evaporation and irrigation rates. Leningrad, Gidrometoizdat, 1970.

7. de Vries Soil food web properties explain ecosystem services across European land use systems. Proceedings of the National Academy of Sciences of the USA 110(35), 14296-14301. DOI: 10.1073/pnas.1305198110, 2013.

8. Didukh Ya. P. The ecological scales for the species of Ukrainian flora and their use in synphytoindication. Kyiv, 2011. Phytosociocentre.

9. EASAC (2015): Ecosystem services, agriculture and neonicotinoids. EASAC policy report 26. $62 \mathrm{~S}$. http://www.interacademies.net/File.aspx?id=27071.

10. EASAC(2015). Ecosystem services, agriculture and neonicotinoids. EASAC policy report 26. $62 \mathrm{~S}$. $\mathrm{http}: / / \mathrm{www}$. interacademies.net/File.aspx?id=27071. 


\section{СІЛЬСЬКЕ ГОСПОДАРСТВО. ЕКОЛОГІЯ}

11. EEA European Environment Agency.The European environment - state and outlook 2010.

12. Foley J. A., DeFries R., Asner G. P., Barford C., Bonan G., Carpenter S. R., Chapin F.S., Coe M. T., Daily G. C., Gibbs H. K., Helkowski J.H., Holloway T., Howard E. A., Kucharik C. J., Monfreda C., Patz J. A., Prentice C., Ramankutty $N$., Snyder P. K. Global consequences of land use. Science 309, 570. 2005. https://doi.org/10.1126/ science. 1111772 .

13. Gallai N., Salles J.-M., Setteled J., Vaissièrea B. E. (2009). Economic valuation of the vulnerability of world agriculture confronted with pollinator decline. Ecological Economics. 68, 810 821. https://doi.org/10.1016/j.ecolecon.2008.06.014

14. Goleusov P. V., Lisetzky F. N. Regeneration of soils in anthropogenically disturbed landscapes of forest-steppe zone. GEOS, 2009. Moscow.

15. Greenleaf S., Williams N.M., Winfree R. Bee foraging ranges and their relationship to body size. Oecologia 153, 2007. - 589-596.

https://doi.org/10.1007/s00442-007-0752-9.

16. Klein A., Steffan-Dewenter I., Tscharntke T. Fruit set of highland coffee increases with the diversity of pollinating bees. Proceedings of the Royal Society of London B 270, 2003. - 955-961.

17. Klein A. M., Vaissière B. E., Cane J.H., Steffan-Dewenter I., Cunningham S. A., Kremen C., Tscharntke $T$. Importance of pollinators in changing landscapes for world crops. Proceedings of the Royal Society of London B 274(1608), 2007. - 303313. DOI: $10.1098 / \mathrm{rspb} .2006 .3721$.

18. Leonhardt S. D., Gallai N., Garibaldi L. A., Kuhlmann M., Klein A. M. Economic gain, stability of pollination and bee diversity decrease from southern to northern Europe. Basic and Applied Ecology, 14, 2013. - 461-471.

http://dx.doi.org/10.1016/j.baae.2013.06.003.

19. Losey J., Vaughan $M$. The economic value of ecological services provided by insects. Bioscience, 56, 2006. - 311-323.

20. Maslikova K.P. The ecological structure of

\section{ANNOTATION}

Maslikova K.P., Zhukov O.V., Kovalenko D.V. Phytoindication assessment of the lighting mode as a marker of regulatory ecosystem services in tehnosoil of Nikopol manganese ore basin.

The research shows the possibility of indication of the regulatory ecosystem services for man-made soilogenesis by means of phytoindication using lighting indicator scale. Field studies were conducted during the 2008-2017 in bioecological research station in Dnipro agro-economic University technosol vegetation of the Nikopol manganese ore basin. Bulletin of Dnipropetrovsk State Agrarian and Economic University. 4 (46), 2017. - 77-88.

21. Masuk N.T. Features of formation of natural and cultural phytocenoses overburden rocks in areas of industrial mining. Land reclamation. Dnipropetrovsk, 1974. -62-105.

22. MEA Millennium Ecosystem Assessment, Ecosystems and Human Well-Being: Synthesis. Island Press, Washington, DC, 2005.

23. Millennium Ecosystem Assessment, 2005. Ecosystems and Human Well-being: Synthesis. Island Press, Washington, DC.

24. Pimentel D., Wilson C., McCullum C., Huang R., Dwen P., Flack J., Tran Q., Saltman T., Cliff B. Economic and environmental benefits of biodiversity. Bioscience 47 (11), 1997. - 747-757.

https://doi.org/10.2307/1313097.

25. TEEB (2010). The economics of ecosystems and biodiversity for national and international policymakers.

26. The EU Biodiversity Strategy to 2020 doi: $10.2779 / 39229$

27. Tsiafouli $M$. Intensive agriculture reduces soil biodiversity across Europe. Global Change Biology 21, 2015. - 973-985.

28. Zhukov O. V., Zadorozhna G. O., Maslikova K. P., Andrusevych K. V., Lyadskaya I. V. Tehnosols Ecology: Monograph. Dnipro: Zhurfond. 2017, 442 p. (in Ukrainian).

29. Zhukov O. V., Pelina T. O. Agroecological analysis of winter wheat yield and it's dynamics in the Dnipropetrovsk region (period 1966-2016). Agrology, 21(3), 2018. -286-293.

30. Zhukov O. V., Pelina T. O., Demchuk O. M., Demchuk N. I., Koberniuk S. O. Agroecological and agroeconomic aspects of the grain and grain legumes (pulses) yield dynamic within the Dnipropetrovsk region (period 1966-2016). Biosystems Diversity, 26(2), 2018. - 170-176. doi:10.15421/011826.

(Pokrov, Dnipropetrovsk region, Ukraine). Polygons incorporated within tehnosoils four types: pedozems, sod-lithogenic soils on forest-like loam, gray-green clay and red-brown clay. Vegetative mass distribution of individual components of complex multi agrophytocenoses, mutual influence aboveground components of each other and environmental conditions under the canopy of vegetation have a significant effect on yield formation of plant communities. A more uniform 


\section{СІЛЬСЬКЕ ГОСПОДАРСТВО. ЕКОЛОГІЯ}

distribution of leaf blades in phytocenoses weakening lighting at the middle and lower tiers won't be very large. It causes the highest intensity operation vegetation photosynthesis per unit area. In order embriozemy $\rightarrow$ sod soils lithogenic $\rightarrow$ pedozemy level assessment phytoindication lighting statistically significantly reduced. Herbaceous vegetation that covers most forms of tehnosoils is formed in the global lighting. Vegetation of the embriozems lighting mode indicates $8.78 \pm 0.01$, sod soils lithogenic $-8.74 \pm 0.02$, pedozems $-8.71 \pm 0.01$.

Key words: ecosystem services, reclamation, phytoindication, lighting mode, sustainable development. 